\title{
Serum uric acid concentrations in a rural Tswana community in Southern Africa
}

\author{
P. BEIGHTON,* L. SOLOMON, C. L. SOSKOLNE, $†$ AND B. SWEET \\ Department of Orthopaedic Surgery, Medical School, University of the Witwatersrand, \\ Johannesburg, South Africa
}

The fact that both the environment and genetic influences play a part in the aetiology of gout has been recognized for many years. Indeed, in the 15 th century, Galen ascribed gout to 'debauchery, intemperance, and a hereditary trait' (Finn, Jones, Tweedie, Hall, Dinsdale, and Bourdillon, 1966).

Although the clinical features of gout are the consequence of hyperuricaemia, a raised concentration of serum uric acid (SUA) does not inevitably lead to gout (Hall, Barry, Dawber, and McNamara, 1967). For this reason, population studies have tended to be concerned with SUA levels rather than their clinical expression.

Population studies in different parts of the world have revealed considerable ethnic and geographical variations in SUA levels. These discrepancies have been ascribed to both genetic and environmental factors. Indeed, in different surveys, the SUA has been correlated with many variables, including age, blood pressure, social status, alcohol intake, somotype, and blood group.

There have been many epidemiological studies of SUA, but investigations of this type do not appear to have been carried out among the indigenous peoples of Southern Africa. For this reason, the SUA was estimated in the 370 adult members of a rural Tswana community in the Western Transvaal, during the course of a large-scale epidemiological survey of bone and joint conditions in this population group. The results obtained are presented and discussed in this paper.

\section{The Tswana and their environment}

The survey was carried out in the village of Phokeng, which is situated at the foot of the Magaliesberg Hills, about 100 kilometers to the north-west of Johannesburg.

The Tswana of Phokeng are members of the Kwena group of Eastern Tswana, a sub-division of the Western Sotho. These peoples are thought to be descended from Negroes of Central Africa, their ancestors having entered Southern Africa in successive waves during the past 2,000 years. It is likely that, in comparatively recent times, the Tswana have had considerable Bushman, Hottentot, and 'Ndebele admixture.

Physically, the Tswana resemble the other indigenous peoples of Southern Africa. The women-folk tend to become obese in middle-age, while the men usually remain thin. Mild degrees of steatopygia are not uncommon, and Bushman-like facial features may sometimes be observed.

The population of Phokeng numbers just over 10,000 ; a relative deficiency of young adults, particularly males, is due to labour migration. The economy is based to a considerable extent upon remittances sent to relatives by individuals working in the cities. Cattle husbandry and small-scale farming are undertaken and food crops, particularly maize, are grown locally. Local produce is supplemented by foodstuffs purchased in the village. In general, the population is adequately fed and malnutrition is uncommon.

\section{Methods}

After a house-to-house census in randomly selected areas of the village, an epidemiologically valid section of the population was chosen for the survey. This group, comprising 1,185 individuals of all ages, was examined clinically and radiologically, while blood specimens were collected from the majority of the adults. The SUA levels were estimated in 370 individuals, whose ages ranged from 18 to 84 years.

Serum was separated within 4 hours of collection, and stored at $-15^{\circ} \mathrm{C}$. for 12 weeks. The SUA levels were determined with an autoanalyser using an automated modification of the Folin method (Buchanan, Isdale, and Rose, 1965). Each autoanalyser run was calibrated against six standards $(2,4,6,8,10$, and $12 \mathrm{mg} . / 100 \mathrm{ml}$.) and against uric acid control sera. The standards were re-estimated after every thirty unknown estimations to maintain constant conditions. In addition, $\mathbf{4 3}$ specimens were estimated by the manual Folin method. The automated version gave results which were, on average, $0.4 \mathrm{mg}$. $/ \mathrm{ml}$. higher than the results obtained by the manual technique. 
The Ponderal Index (PI), an expression of somotype, was calculated for each individual by dividing the height in inches by the cube root of the weight in pounds. According to Acheson and Chan (1969), a PI of 10.5 indicates considerable obesity, while a level of 14.0 would be applicable to a very thin person.

The data were coded and computerized and, where appropriate, a fitted curve was used to express the results. The curve was determined by means of the method of 'least squares', a statistical procedure which minimizes the sum of the squares of the vertical distances of plotted points to a trend line. This technique is of value for indicating trends in data.

\section{Results}

Clinical and radiological examinations failed to reveal any objective evidence of gout in the community and no patient gave a history which was suggestive of an acute gouty attack.

The average SUA values, related to age and sex, are shown in Fig. 1. Young adult males had higher levels than females of the same age. The average concentrations rose slowly with age in both sexes, the levels of the females reaching those of the males by the age of 50 years. Thereafter, both sexes maintained approximately equal SUA concentrations.

The mean, standard deviation, and range of SUA values are shown for males and females in Table $I$. In virtually every cohort, isolated individuals had SUA levels which were outside the 'normal' range of 3.5 to $7.0 \mathrm{mg}$. per cent. in males, and 3.5 to $6 \mathrm{mg}$. per cent. in females.

The relationship between SUA and PI in adults is shown in Table II (overleaf). The correlation coefficients of -0.356 for the males and -0.338 for

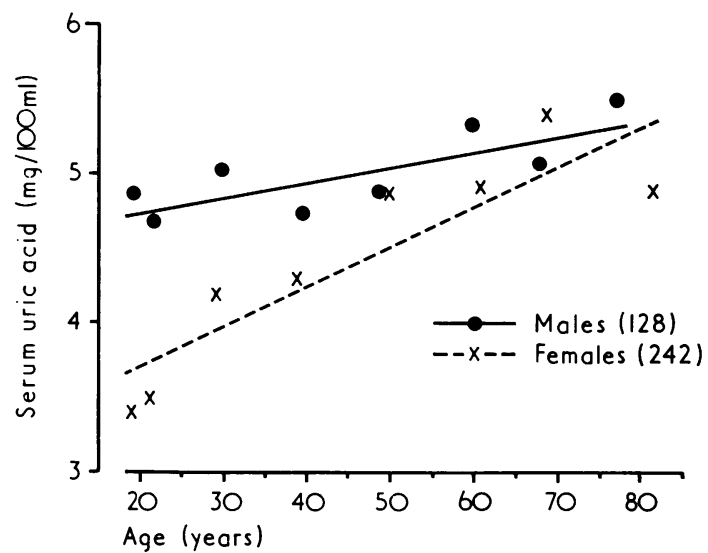

FIG. 1 Average SUA levels, in relation to age and sex, shown by a 'fitted' curve

the females indicate a positive relationship between the SUA and somotype, the more obese individuals having higher SUA levels.

The frequency distribution of SUA levels for males and females is shown in Fig. 2 (overleaf). The slight shift to the left of the curve for the females compared to that of the males is in agreement with their respective mean values. Both curves are unimodal, and on the basis of this data there is no evidence to contradict the hypothesis that the SUA levels in the population are normally distributed.

\section{Discussion}

Epidemiological studies have demonstrated significant variations of SUA concentrations in different

Table I Tswana Survey. Serum uric acid levels (mean, standard deviation, and range), by sex and age group

\begin{tabular}{|c|c|c|c|c|c|c|}
\hline \multirow[t]{2}{*}{ Sex } & \multirow{2}{*}{$\begin{array}{l}\text { Age group } \\
\text { (yrs) }\end{array}$} & \multirow{2}{*}{$\begin{array}{l}\text { No.of } \\
\text { patients }\end{array}$} & \multirow{2}{*}{$\begin{array}{l}\text { Mean SUA } \\
\text { (mg. per cent.) }\end{array}$} & \multirow[t]{2}{*}{$S D$} & \multicolumn{2}{|c|}{ Range (mg. per cent.) } \\
\hline & & & & & Low & High \\
\hline Males & $\begin{array}{l}14-19 \\
20-24 \\
25-34 \\
35-44 \\
45-54 \\
55-64 \\
65-74 \\
75-84 \\
\text { Total }\end{array}$ & $\begin{array}{r}26 \\
20 \\
10 \\
11 \\
11 \\
19 \\
20 \\
11 \\
128\end{array}$ & $\begin{array}{l}4 \cdot 84 \\
4 \cdot 67 \\
5 \cdot 02 \\
4 \cdot 72 \\
4 \cdot 87 \\
5 \cdot 31 \\
5 \cdot 06 \\
5 \cdot 46 \\
4 \cdot 90\end{array}$ & $\begin{array}{l}0.61 \\
0.92 \\
1.02 \\
1.07 \\
1.49 \\
1.50 \\
0.89 \\
1.21 \\
1.09\end{array}$ & $\begin{array}{l}3.5 \\
2.9 \\
3 \cdot 1 \\
2.9 \\
3 \cdot 0 \\
3 \cdot 7 \\
3 \cdot 7 \\
4 \cdot 1 \\
2.9\end{array}$ & $\begin{array}{c}6 \cdot 0 \\
6.5 \\
6.8 \\
6.5 \\
7.4 \\
10.6 \\
7.4 \\
8.1 \\
10.6\end{array}$ \\
\hline Females & $\begin{array}{l}14-19 \\
20-24 \\
25-34 \\
35-44 \\
45-54 \\
55-64 \\
65-74 \\
75-84 \\
85-95 \\
\text { Totals }\end{array}$ & $\begin{array}{r}24 \\
24 \\
22 \\
24 \\
31 \\
49 \\
40 \\
21 \\
7 \\
242\end{array}$ & $\begin{array}{l}3.40 \\
3.51 \\
4 \cdot 11 \\
4.28 \\
4.87 \\
4.93 \\
5.38 \\
5.00 \\
4.73 \\
4.46\end{array}$ & $\begin{array}{l}0.90 \\
0.92 \\
1.13 \\
1.60 \\
1.52 \\
1.60 \\
1.08 \\
0.68 \\
0.94 \\
1.09\end{array}$ & $\begin{array}{l}2.1 \\
2.0 \\
2 \cdot 4 \\
1 \cdot 1 \\
1.4 \\
2.6 \\
2 \cdot 6 \\
3 \cdot 6 \\
3.2 \\
1.1\end{array}$ & $\begin{array}{r}5 \cdot 8 \\
6 \cdot 3 \\
6 \cdot 7 \\
8 \cdot 4 \\
8 \cdot 0 \\
11 \cdot 1 \\
7 \cdot 7 \\
6 \cdot 6 \\
6 \cdot 3 \\
11 \cdot 1\end{array}$ \\
\hline
\end{tabular}


Table II Ponderal index and serum uric acid in patients aged 20 yrs and over, by sex

\begin{tabular}{|c|c|c|c|c|c|}
\hline Sex & $\begin{array}{l}\text { Ponderal } \\
\text { index } \\
\text { (No. of cases) }\end{array}$ & $S D$ & $\begin{array}{l}\text { Correlation } \\
\text { coefficient } \\
\text { (No. of cases) }\end{array}$ & $\begin{array}{l}\text { SUA } \\
\text { (No. of cases) }\end{array}$ & $S D$ \\
\hline Male & $\begin{array}{l}12.99 \\
(140)\end{array}$ & 0.64 & $\begin{array}{l}-0.356 \\
(86)\end{array}$ & $\begin{array}{l}5 \cdot 0 \\
(102)\end{array}$ & $1 \cdot 12$ \\
\hline Female & $\begin{array}{l}12.06 \\
(278)\end{array}$ & 0.92 & $\begin{array}{l}-0.338 \\
(182)\end{array}$ & $\begin{array}{l}4 \cdot 7 \\
(218)\end{array}$ & 1.42 \\
\hline
\end{tabular}

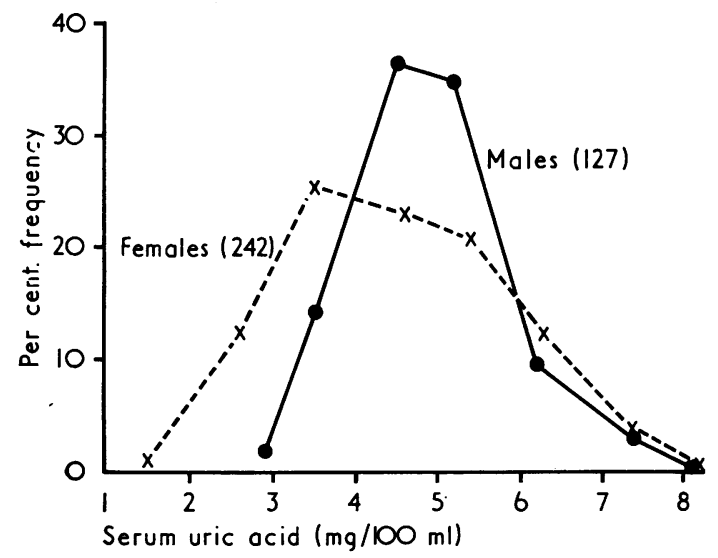

FIG. 2 Frequency distribution of SUA levels in males and females

racial groups. For example, the Polynesians of the Western Pacific and the Maoris of New Zealand have a tendency to hyperuricaemia and gout (Prior, Rose, and Davidson, 1964; Burch, O'Brien, Need, and
Kurland, 1966; Prior, Rose, Harvey, and Davidson, 1966; Evans, Prior, and Harvey, 1968) while the Chinese of Taiwan and the Indians of New Delhi have low SUA levels (Deb, Gupta, Bhargava, and Sharma, 1968).

These differences could be due to genetic factors or to environmental influences. However, the environment is certainly of importance, as Chinese who emigrated to British Columbia and Malaya have higher SUA levels (Ford and de Mos, 1964) than their relatives who remained in Taiwan.

The SUA concentrations in the Tswana are similar to the mean levels reported for European communities but lower than those of North America and Pacific populations (Table III). However, it is difficult to make direct comparisons as patients of different age groups were chosen in the various surveys.

The factors which determine the SUA levels in the Tswana can only be a matter for speculation, but a moderate diet and stress-free environment may be of significance. In Andean populations, altitude of domicile and SUA have been found to be related (Acheson, 1970). As the Phokeng Tswana live at

Table III Mean serum uric acid levels in normal populations

\begin{tabular}{|c|c|c|c|c|c|}
\hline \multirow[t]{2}{*}{ Authors } & \multirow[t]{2}{*}{ Date } & \multirow[t]{2}{*}{ Locality } & \multirow{2}{*}{$\begin{array}{l}\text { Age range } \\
(y r s)\end{array}$} & \multicolumn{2}{|c|}{ Mean serum uric acid } \\
\hline & & & & Male & Female \\
\hline \multirow[t]{2}{*}{ Popert and Hewitt } & 1962 & Wensleydale, UK & $15-54$ & $4.7 \pm 0.9$ & $3 \cdot 8 \pm 0.8$ \\
\hline & & Leigh, UK & $55-64$ & $4 \cdot 9 \pm 1 \cdot 2$ & $4 \cdot 3 \pm 1 \cdot 1$ \\
\hline Mikkelsen and others & 1965 & Tecumseh, USA & $20-49$ & $5 \cdot 2 \pm 1 \cdot 3$ & $4 \cdot 1 \pm 1 \cdot 2$ \\
\hline Gjorup, Poulsen, and Praetorius & 1955 & Copenhagen & $20-90$ & $5 \cdot 0 \pm 1 \cdot 2$ & $3.8 \pm 0.9$ \\
\hline Duff, Mikkelsen, Dodge, and Himes & 1968 & Philippines & $20-49$ & $6 \cdot 0 \pm 1 \cdot 2$ & $4 \cdot 2 \pm 1 \cdot 0$ \\
\hline Rose and Prior & 1963 & (Maori) NZ & $15-49$ & $7 \cdot 1 \pm 1 \cdot 3$ & $\overline{5 \cdot 8 \pm 1 \cdot 6}$ \\
\hline \multirow[t]{2}{*}{ O'Brien and others } & 1966 & (Blackfeet) USA & $30+$ & $5 \cdot 2 \pm 1 \cdot 1$ & $4 \cdot 5 \pm 1 \cdot 2$ \\
\hline & & (Pima) USA & $30+$ & $4 \cdot 6 \pm 1 \cdot 2$ & $3.9 \pm 1 \cdot 0$ \\
\hline \multirow[t]{3}{*}{ Muller } & 1970 & W. Africa & $5-55$ & $\begin{array}{l}3.9 \pm 0.9 \\
4.8 \pm 0.7\end{array}$ & $\begin{array}{l}3.5 \pm 0.9 \\
3.6 \pm 0.7\end{array}$ \\
\hline & & Tswana & $15-84$ & $4 \cdot 8 \pm 1 \cdot 0$ & $4 \cdot 4 \pm 1 \cdot 0$ \\
\hline & & Nama & $15-84$ & $5 \cdot 7 \pm 1 \cdot 2$ & $5 \cdot 0 \pm 1 \cdot 1$ \\
\hline
\end{tabular}


an altitude of 1,300 metres, this factor may influence their SUA concentrations, although it is more likely that this relationship only becomes significant at higher altitudes.

The SUA levels in the Tswana gradually increase with age, those of the males remaining higher than those of the females until the middle of the life span. This finding is in accordance with the results of other epidemiological studies (Mikkelsen, Dodge, and Valkenburg, 1965; Emmerson, Douglas, Dougherty, and Feigel, 1969).

A few individuals in the survey group had SUA levels which were unusually high or low. As no further investigations were carried out on these subjects, it is not known if the high levels were due to underlying conditions such as renal disease or blood dyscrasia. Similarly, disorders such as xanthinuria were not excluded as a cause of hypouricaemia.

The PI gives a good estimate of obesity, and the SUA levels in the Tswana were found to be directly related to this attribute. Similar observations have been made in several other populations, including American Indians (O'Brien, Burch, and Bunim, 1966), and the inhabitants of New Haven, U.S.A. (Acheson and Chan, 1969).

The unimodality of the frequency distribution curve for SUA concentration in the Tswana implies that hyperuricaemia is not a monogenic trait. O'Brien and others (1966) recognized unimodality of SUA frequency distribution in American Indian populations, and on a basis of studies of SUA levels in family groups, they concluded that heritability was low. For this reason, it is probable that hyperuricaemia is largely determined by environmental factors.

As in many parts of the world, the inhabitants of rural areas of Southern Africa are tending to move to the cities and to adopt an increasingly sophisticated way of life. The fresh environmental factors which are inevitably encountered in this situation may interact with basic genetic attributes to produce metabolic changes and disease entities. For instance, gout is thought to be rare in indigenous rural populations in
Southern Africa, although it is known to occur in urban African communities.

The normal SUA concentrations in the rural Tswana have been defined in the present investigation. In the near future it is hoped to carry out a comparative study of SUA levels in urbanized members of the same ethnic group. This investigation will permit an assessment of the significance of the change of environment in the determination of SUA levels.

\section{Summary}

SUA concentrations were measured in 370 adults in a rural Tswana community in the Western Transvaal.

At any age the average SUA levels were similar to those reported for European populations. The SUA of the males was consistently higher than that of the females until middle-age. Thereafter, both sexes had approximately equal SUA concentrations. The frequency distribution curves for the SUA concentrations were unimodal.

SUA levels were directly related to obesity, as expressed by the Ponderal Index, in both sexes.

No clinical gout was encountered, although a few individuals had SUA levels in the hyperuricaemic range.

We are indebted to the President of the Human Sciences Research Council, Pretoria, for providing computer facilities and to the photographic staff of the Orthopaedic Department, for their assistance in the preparation of the illustrations.

This research was supported jointly by the Orthopaedic Chair Trust Fund and the Carl and Emily Fuchs Foundation.

We are grateful to Chief Mokgatle and the Department of Bantu Administration for permission to undertake this investigation.

Miss Liz Paget and Mrs. Fifi Sparrow typed the manuscript with their usual enthusiasm and efficiency.

We are especially grateful to the Tswana of Phokeng for their good natured participation in the survey.

P.B. was in receipt of a Geigy fellowship awarded by the Arthritis and Rheumatism Council of Great Britain.

\section{References}

ACHeSon, R. M. (1970) Proc. roy. Soc. Med. 63, 193 (Epidemiology of serum uric acid and gout: an example of the complexities of multifactorial causation)

and Chan, Y. K. (1969) J. Chron. Dis., 21, 543 (New Haven Survey of Joint Diseases. Prediction of serum uric acid in a general population)

Buchanan, W. W., Isdale, I. C., AND Rose, B. S. (1965) Ann. rheum. Dis., 24, 285 (Serum uric acid estimation)

Burch, T. A., O’Brien, W. M., Need, R., AND Kurland, L. T. (1966) Ibid., 25, 114 (Hyperuricaemia and gout in the Mariana Islands)

Deb, S. R., Gupta, G. D., Bhargava, S. P., ANd Sharma, M. L. (1968) J. Indian med. Ass., 51, 363 (Normal serum uric acid levels in Indians)

Duff, I. F., Mikkelsen, W. M., Dodge, H. J., ANd Himes, D. S. (1968) Arthr. and Rheum., 11, 184 (Comparison of uric acid levels in some oriental and caucasian groups unselected as to gout or hyperuricaemia)

Emmerson, B. T., Douglas, W., Doherty, R. L., And Feigl, P. (1969) Ann. rheum. Dis., 28, 150 (Serum urate concentrations in the Australian aboriginal)

Evans, J. G., Prior, I. A. M., AND HARVEY, H. P. B. (1968) Ibid., 27, 319 (Relation of serum uric acid to body bulk, haemoglobin, and alcohol intake in two South Pacific Polynesian populations) 
Finn, R., Jones, P. O., Tweedie, M. C. K., Hall, S. M., Dinsdale, O. F., and Bourdillon, R. E. (1966) Lancet, 2, 185 (Frequency-distribution curve of uric acid in the general population)

Ford, D. K., AND DE Mos, A. M. (1964) Canad. med. Ass. J., 90, 1925 (Serum uric acid levels of healthy Caucasian, Chinese, and Haida Indian males in British Columbia)

GJoRuP, S., Poulsen, H., AND Praetorius, E. (1955) Scand. J. clin. Lab. Invest., 7, 201 (The uric acid concentration in serum determined by enzymatic spectrophotometry)

Hall, A. P., Barry, P. E., Dawber, T. R., and McNamara, P. M. (1967) Amer. J. Med., 42, 27 (Epidemiology of gout and hyperuricaemia)

Mikkelsen, W. M., Dodge, H. J., ANd Valkenburg, H. A. (1965) Ibid., 39, 242 (The Distribution of serum uric acid values in a population unselected as to gout or hyperuricaemia)

Muller, A. S. (1970) M.D. Thesis Leiden, p. 129 (Population studies on the prevalence of rheumatic diseases in Liberia and Nigeria)

O'Brien, W. M., BURCh, T. A., AND Bunim, J. J. (1966) Ann. rheum. Dis., 25, 117 (Genetics of hyperuricaemia in Blackfeet and Pima Indians)

POPERT, A. J., AND HewITT, J. V. (1962) Ibid., 21, 154 (Gout and hyperuricaemia in rural and urban populations)

Prior, I. A. M., Rose, B. S., ANd Davidson, F. (1964) Brit. med. J., 1, 1065 (Metabolic maladies in New Zealand Maoris)

,-- , HARVEY, H. P. B., AND Davidson, E. (1966) Lancet, 1, 333 (Hyperuricaemia, gout, and diabetic abnormality in Polynesian people)

Rose, B. S., AND PRIOR, I. A. M. (1963) Ann. rheum. Dis., 22, 410 (A survey of rheumatism in a rural New Zealand Maori community) 